HNO 2021 $69: 303-311$

https://doi.org/10.1007/s00106-021-01021-4

Accepted: 24 January 2021

Published online: 5 March 2021

(c) The Author(s) 2021

Patrick J. Schuler' 1 - Jens Greve' - Thomas K. Hoffmann' · Janina Hahn' •

Felix Boehm ${ }^{1}$ - Bastian Bock ${ }^{2}$. Johannes Reins ${ }^{2}$. Ulrich Ehrmann ${ }^{3}$. Eberhard Barth ${ }^{2} \cdot$ Karl Traeger $^{2} \cdot$ Bettina Jungwirth ${ }^{2} \cdot$ Martin Wepler $^{2}$

'Department of Oto-Rhino-Laryngology, Head and Neck Surgery, Ulm University Medical Center, UIm, Germany

${ }^{2}$ Department of Anesthesiology and Intensive Care, UIm University Medical Center, UIm, Germany

${ }^{3}$ Department of Anesthesiology and Intensive Care, Ehingen Hospital, Ehingen, Germany

\title{
Surgical tracheostomy in a cohort of COVID-19 patients
}

fore potentially increase the availability of ICU beds $[14,18]$. However, in COVID19 patients, tracheostomy itself and the optimal time point is a matter of considerable debate, mainly because of the increased risk for contamination of the medical staff during the procedure $[2,21]$. The American Academy of Otolaryngology-Head and Neck Surgery suggests delaying tracheostomy in these patients for as long as possible [9]. They recommend performing the procedure only in those patients who display clinical signs of improvement, which implies a reduced virus load. This is typically the case after 2-3 weeks of ventilation. Other recommendations are to perform tracheostomy not before two negative SARS-CoV2 tests have been obtained [10] or only when the expected chance of recovery is high [9]. Importantly, all front of neck airway (FONA) procedures in COVID-19 patients are potentially associated with increased aerosol generation and virus exposure. Therefore, special precautions for personal protection should be followed by the surgeons $[4,38]$.

In the COVID-19 patients at our department, tracheostomy was performed at the earliest convenience because it may facilitate the ventilation of these patients and improve patient recovery. We decided to perform an open surgical tracheostomy by our Ear, Nose and Throat (ENT) specialists in all patients because of potential advantages compared to a dilatational tracheostomy: potentially lower risk for contamination during the procedure due to surgical preparation of the trachea, secured airway also during accidental dislocation of the tracheal tube when placing patients into prone position [3], waiving of bronchoscopy with additional aerosol production [26], and obesity as a frequent comorbidity in COVID-19 patients as a relative contraindication for dilatational tracheostomy.

\section{Methods}

Study population. All included patients $(n=18)$ had confirmed infection with SARS-CoV-2 and needed mechanical ventilation because of severe hypoxemic respiratory failure (Horovitz index $<150 \mathrm{~mm} \mathrm{Hg}\left[\mathrm{PaO}_{2}\right.$ \{partial pressure of arterial oxygen in the systemic arterial blood, $\mathrm{mm} \mathrm{Hg}$ \} divided by $\mathrm{F}_{\mathrm{i}} \mathrm{O}_{2}$ \{fraction of inspired oxygen, \%\}]) [18]. In general, all patients on mechanical ventilation due to COVID-19 on our ICU were intended for tracheostomy. In 4 patients of our COVID-19 cohort during March to May 2020, we decided to not perform tracheostomy due to severe multiorgan failure (MOF) from the very beginning of the disease [23]. The study was approved by the local ethics committee (\#124/20). Informed consent was waived, and only anonymized data were analyzed.

\section{Confirmation of SARS-CoV-2 infection.}

All patients in the study tested positive for SARS-CoV-2 infection by deep throat swabs $(n=7)$, by bronchial lavage $(n=5)$ or both $(n=6)$. Screening for virus RNA 


\section{Original articles}

\section{Table 1 Baseline characteristics}

\begin{tabular}{|c|c|c|}
\hline & Survivor & Nonsurvivor \\
\hline Patients ( $n$ ) & $12(67 \%)$ & $6(33 \%)$ \\
\hline Age, median (range) & $63(42-81)$ & $75(58-87)$ \\
\hline Sex (male/female) & $10 / 2$ & $5 / 1$ \\
\hline$B M I^{\mathrm{a}}$, median (range) & $32(25-39)$ & $28(26-37)$ \\
\hline Patients on extracorporeal membrane oxygenation (ECMO) & $2(17 \%)$ & $0(0 \%)$ \\
\hline \multicolumn{3}{|l|}{ Pre-existing conditions } \\
\hline Hypertension & $9(75 \%)$ & $4(67 \%)$ \\
\hline Obesity (BMI > 30) & $8(67 \%)$ & $2(33 \%)$ \\
\hline Diabetes & $6(50 \%)$ & $2(33 \%)$ \\
\hline Coronary artery disease & $3(25 \%)$ & $1(17 \%)$ \\
\hline Hyperlipoproteinemia & $6(50 \%)$ & $1(17 \%)$ \\
\hline Chronic kidney disease & $2(17 \%)$ & $2(33 \%)$ \\
\hline Chronic obstructive pulmonary disease & $3(25 \%)$ & $0(0 \%)$ \\
\hline Obstructive sleep apnea syndrome & $2(17 \%)$ & $0(0 \%)$ \\
\hline Hypothyroidism & $3(25 \%)$ & $0(0 \%)$ \\
\hline Cancer ${ }^{b}$ & $2(17 \%)$ & $1(17 \%)$ \\
\hline \multicolumn{3}{|l|}{ Diagnostics ${ }^{\mathrm{C}}(\boldsymbol{n})$} \\
\hline Chest X-ray & 14 & 4 \\
\hline Pulmonary CT scan & 7 & 3 \\
\hline Throat swap positive & 10 & 3 \\
\hline Bronchial lavage positive & 9 & 2 \\
\hline $\begin{array}{l}\text { Days between oral intubation and surgical tracheostomy } \\
\text { (median; range) }\end{array}$ & $10(2-16)$ & $7(4-12)$ \\
\hline \multicolumn{3}{|c|}{$\begin{array}{l}{ }^{a} \text { Body mass index (BMI) is body weight in kilograms divided by the square of the height in meters } \\
{ }^{\text {b }} \text { Cancer included bladder cancer, testicular cancer, and acute myeloid leukemia } \\
\text { 'Patients may have received both chest X-ray and pulmonary computed tomography (CT) scan or } \\
\text { deep throat swab and bronchial lavage }\end{array}$} \\
\hline
\end{tabular}

was performed by reverse transcription polymerase chain reaction (RT-PCR).

\section{Blood, ventilation, and hemodynamic} parameters. Parameters were determined on admission to ICU and daily during intensive care treatment. The following ventilation parameters were determined once daily during invasive ventilation: peak pressure, $\mathrm{PaO}_{2}, \mathrm{~F}_{\mathrm{i}} \mathrm{O}_{2}$, Horovitz index, positive end-expiratory pressure (PEEP), and lung compliance. In addition, the dose of sufentanil, midazolam and norepinephrine, as well as the need for neuromuscular blocking agents, transfusion or dialysis was documented daily. Patients were brought into prone position for $16 \mathrm{~h}$ daily if they showed severe hypoxemia under mechanical ventilation (Horovitz index $<150 \mathrm{~mm} \mathrm{Hg}$, [8]).

Surgery. Open tracheostomy in all study patients $(n=18)$ was performed in the patient's ICU bed with sterile draping. In all patients, oral nutrition was stopped for a minimum of $6 \mathrm{~h}$ prior to received open surgical tracheostomy, for which they received neuromuscular blocking agents to avoid coughing or pressing. Each procedure was performed by two head and neck surgeons, two scrub nurses and two anesthetists. All involved staff were well experienced. Overall, six different ENT surgeons and six different anesthetists were involved, who were protected by N99mask and facial shield $(n=6)$ or by powered air-purifying respirator (PAPR, $n=6)$. PAPR equipment was provided by $3 \mathrm{M}$ (Versaflo, St. Paul, MN, USA) and PM (e-breathe, Mönchengladbach, Germany). Scrub nurses used N99masks with a facial shield. Surgical steps were performed using Björk's technique [17]. Before surgical opening of the trachea, ventilation was stopped, and surgery. All included patients $(n=18)$ the cuff was deflated. The transoral tube was advanced well into the trachea to decrease aerosol generation and viral exposure due to possible cuff dysfunction caused by the surgical instruments. For advancing the tracheal cannula, ventilation was stopped again, and the oral tube was removed with deflated cuff. All patients were provided with a 9.0 $\mathrm{CH}$ high to low cuffed $(34.0 \mathrm{~mm})$ tracheostomy tube (Covidien ${ }^{\mathrm{TM}}$, Mansfield, MA, USA, $9.0 \mathrm{~mm}$ inner diameter and $12.2 \mathrm{~mm}$ outer diameter). In one patient, leakage at the tracheostoma was detected immediately after the procedure, so that 9.0 $\mathrm{CH}$ tracheal tube was changed to a $10.0 \mathrm{CH}$ high to low cuffed $(35.0 \mathrm{~mm})$ tracheostomy tube (Covidien ${ }^{\mathrm{TM}}$, Mansfield, MA, USA, $10.0 \mathrm{~mm}$ inner diameter and $13.6 \mathrm{~mm}$ outer diameter). All other surgical procedures were uneventful.

Statistical analysis. Continuous and categorical variables were presented as median and interquartile range (IQR) or absolute range. Due to the retrospective observational study design and therefore the irregular number of patients at each day before and after tracheostomy, we waived any statistical analysis and present our data only descriptively.

\section{Results}

\section{Clinical characteristics of the patients}

From March 27 and May 18, 2020, open surgical tracheostomy was performed on COVID-19 patients $(n=18)$ because of acute respiratory failure, but without severe MOF at a tertiary care university hospital in Germany. The age range was 42-87 years, with most of the patients being male $(15 / 18,83.3 \%)$. Patients' baseline characteristics, including pre-existing conditions, are presented in $\bullet$ Table 1.

\section{Surgical staff}

No COVID-19 infection was detected in any of the staff who were involved in the surgical procedures. In addition, none of the staff had developed symptoms within three weeks after the procedure. All involved surgeons, anesthetists and scrub 
HNO 2021 -69:303-311 https://doi.org/10.1007/s00106-021-01021-4

(c) The Author(s) 2021

\section{P. J. Schuler · J. Greve · T. K. Hoffmann · J. Hahn · F. Boehm • B. Bock · J. Reins · U. Ehrmann · E. Barth · K. Traeger · B. Jungwirth · M. Wepler}

\section{Surgical tracheostomy in a cohort of COVID-19 patients}

\section{Abstract}

Background. One of the main symptoms of severe infection with the new coronavirus-2 (SARS-CoV-2) is hypoxemic respiratory failure because of viral pneumonia with the need for mechanical ventilation. Prolonged mechanical ventilation may require a tracheostomy, but the increased risk for contamination is a matter of considerable debate.

Objective. Evaluation of safety and effects of surgical tracheostomy on ventilation parameters and outcome in patients with COVID-19.

Study design. Retrospective observational study between March 27 and May 18, 2020, in a single-center coronavirus diseasedesignated ICU at a tertiary care German hospital.

Patients. Patients with COVID-19 were treated with open surgical tracheostomy due to severe hypoxemic respiratory failure requiring mechanical ventilation.

Measurements. Clinical and ventilation data were obtained from medical records in a retrospective manner.

Results. A total of 18 patients with confirmed SARS-CoV-2 infection and surgical tracheostomy were analyzed. The age range was $42-87$ years. All patients received open tracheostomy between 2-16 days after admission. Ventilation after tracheostomy was less invasive (reduction in PEAK and positive end-expiratory pressure [PEEP]) and lung compliance increased over time after tracheostomy. Also, sedative drugs could be reduced, and patients had a reduced need of norepinephrine to maintain hemodynamic stability. Six of 18 patients died. All surgical staff were equipped with N99-masks and facial shields or with powered air-purifying respirators (PAPR)

Conclusion. Our data suggest that open surgical tracheostomy can be performed without severe complications in patients with COVID-19. Tracheostomy may reduce invasiveness of mechanical ventilation and the need for sedative drugs and norepinehprine. Recommendations for personal protective equipment (PPE) for surgical staff should be followed when PPE is available to avoid contamination of the personnel.

Keywords

Tracheostomy - Coronavirus - Surgery . Mortality · Ventilation

\section{Chirurgische Tracheostomie in einer Kohorte von COVID-19-Patienten}

\section{Zusammenfassung}

Hintergrund. Ein Hauptsymptom der schweren Infektion mit dem neuen Coronavirus-2 (SARS-CoV-2) ist das hypoxämische Atemversagen aufgrund einer Viruspneumonie, welches eine mechanische Beatmung erfordert. Eine längere mechanische Beatmung erfordert ggf. eine Tracheostomie, welche aufgrund des erhöhten Kontaminationsrisikos jedoch umstritten ist.

Ziel. Bewertung von Sicherheit und Auswirkungen der chirurgischen Tracheostomie auf Beatmungsparameter und Überleben bei Patienten mit COVID-19.

Studiendesign. Retrospektive Beobachtungsstudie zwischen 27. März und 18. Mai 2020 auf einer COVID-Intensivstation in einem Krankenhaus der Tertiärversorgung.
Patienten. Patienten mit COVID-19 wurden wegen schweren hypoxämischen Atemversagens mit offener chirurgischer Tracheostomie behandelt.

Messungen. Klinische Daten und Beatmungsparameter wurden retrospektiv aus medizinischen Unterlagen entnommen.

Ergebnisse. Analysiert wurden die Daten von 18 Patienten mit chirurgischer Tracheostomie bei bestätigter SARS-CoV-2-Infektion. Die Altersspanne betrug 42-87 Jahre. Bei allen Patienten erfolgte zwischen 2 und 16 Tage nach der Aufnahme eine offene Tracheostomie. Anschließend war die Beatmung weniger invasiv, die Lungen-Compliance nahm zu und die Sedierung konnte reduziert werden. Es starben 6 von 18 Patienten. Alle chirurgischen
Mitarbeiter waren mit FFP3-Masken oder mit motorbetriebenen luftreinigenden Atemschutzmasken ausgestattet. Schlussfolgerung. Die vorliegenden Daten legen nahe, dass eine offene chirurgische Tracheostomie ohne schwerwiegende Komplikationen durchgeführt werden kann. Diese kann die Invasivität der mechanischen Beatmung sowie den Bedarf an Beruhigungsmitteln und Katecholaminen verringern. Falls verfügbar, sollten Empfehlungen für die persönliche Schutzausrüstung befolgt werden.

Schlüsselwörter

Tracheostomie - Corona - Chirurgie ·

Sterblichkeit $\cdot$ Beatmung nurses were confirmed to be negative for SARS-CoV-2 by one deep throat swab at the time of the data lock.

\section{Outcomes}

At the time of the data lock on May 18, $12 / 18(66.6 \%)$ patients had been transferred to a peripheral care ward or rehabilitation center. In 5/18 (27.7\%) patients, the tracheal cannula had been removed and the tracheostoma was cov- ered before discharge (median 9 days after tracheostomy). However, 2/18 (11\%) patients were transferred to a rehabilitation center under invasive ventilation via a tracheal tube. In total, 10/18 (55.5\%) patients had been taken off ventilation, and 6/18 (33.3\%) patients had deceased (• Fig. 1).

\section{Ventilation and hemodynamic parameters}

Peak pressure could be slightly reduced over time after tracheostomy. Lung compliance increased over time at least during the first five days after tracheostomy (- Fig. 2a, b). The Horovitz index as a marker for oxygenation slightly increased over time after tracheostomy, whereas the PEEP could be reduced. The course of Horovitz index and PEEP 


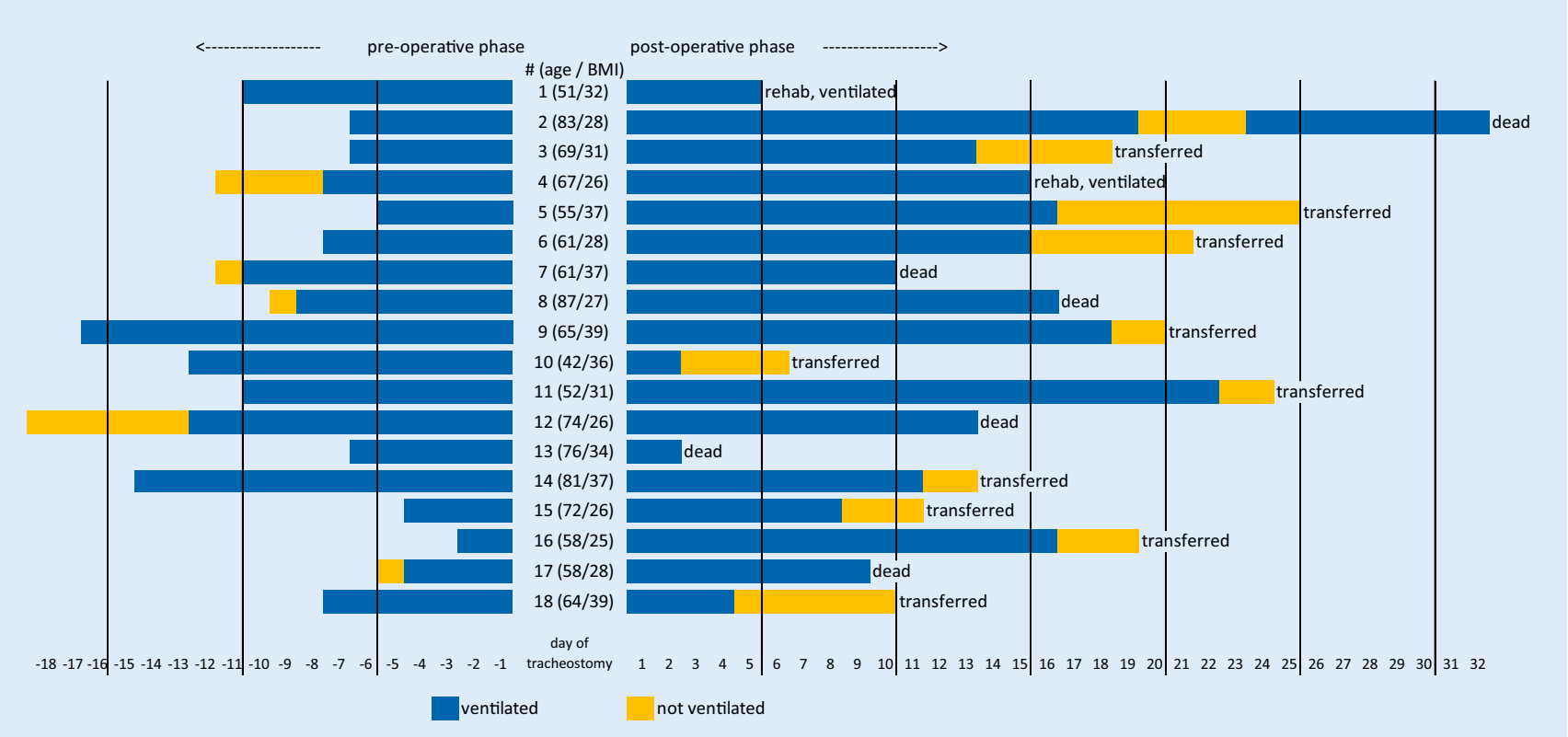

Fig. $1 \Delta$ Outcomes for individual patients. Day of surgical tracheostomy is defined as day 0. Preoperative phase includes day -18 until day -1. Postoperative phase includes days 1 to 32 . Rehab early rehabilitation facility. BMI body mass index in the body weight in kilograms divided by the square of the height in meters. At the time of the data lock (May 18, 2020), 12 patients (66.6\%) had been discharged from the ICU, and 6 patients (33.3\%) had died

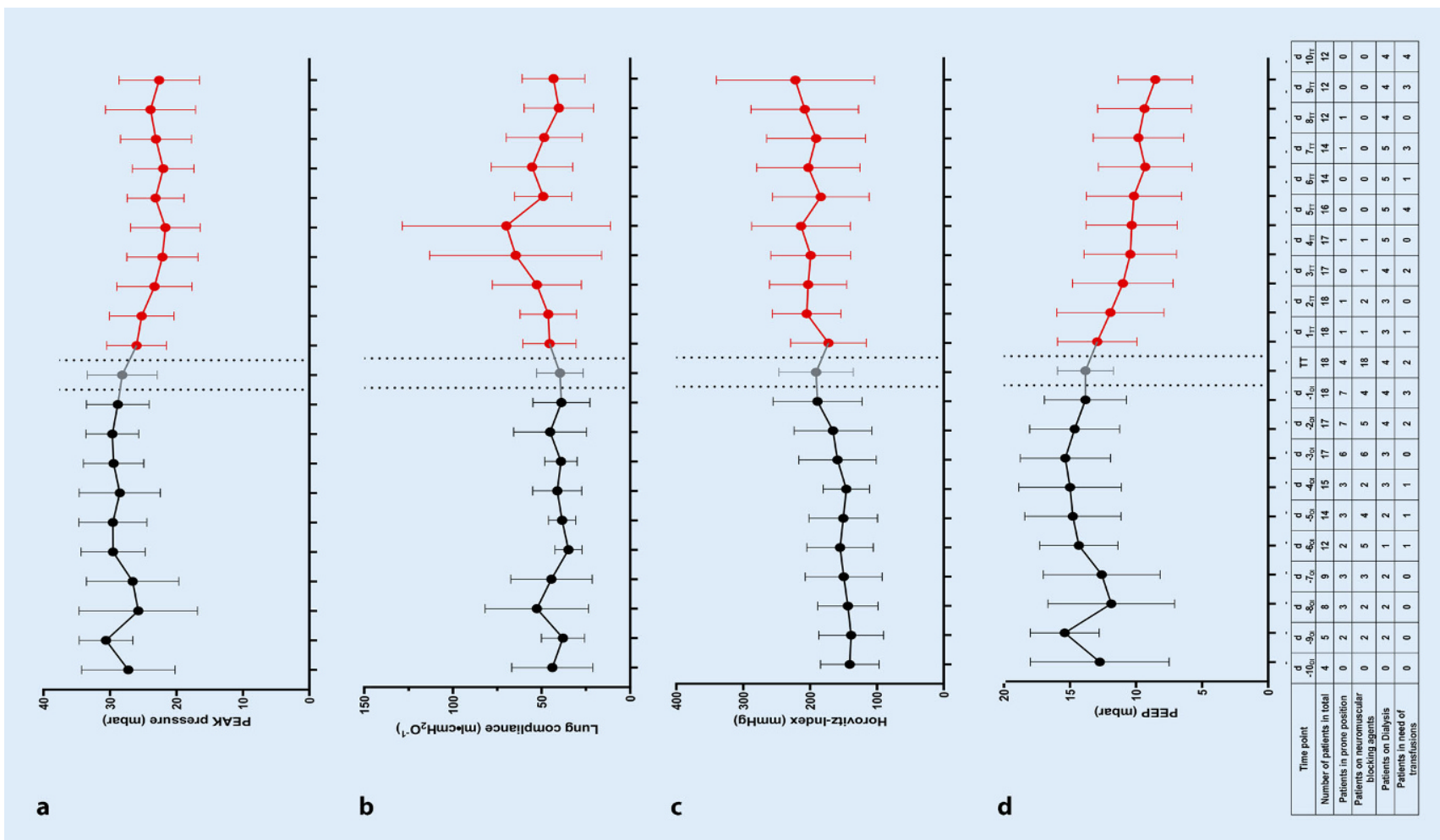

Fig. $2 \Delta$ Ventilation parameters in the period from 10 days before surgical tracheostomy until 10 days after tracheostomy: a peak pressure ( $\mathrm{mbar}$ ), b static lung compliance (tidal volume divided by driving pressure, $\mathrm{ml} \cdot \mathrm{cmH}_{2} \mathrm{O}$ ), $\mathbf{c}$ Horovitz index as a marker of oxygenation (partial pressure of arterial oxygen divided by the fraction of inspired oxygen, $\mathrm{mm} \mathrm{Hg}$ ), and d positive end-expiratory pressure (PEEP, mbar). After surgery, the number of patients in need for prone position and neuromuscular blocking agents was reduced whereas the number of patients requiring dialysis and blood transfusion increased (table). Data are presented as median and interquartile range 


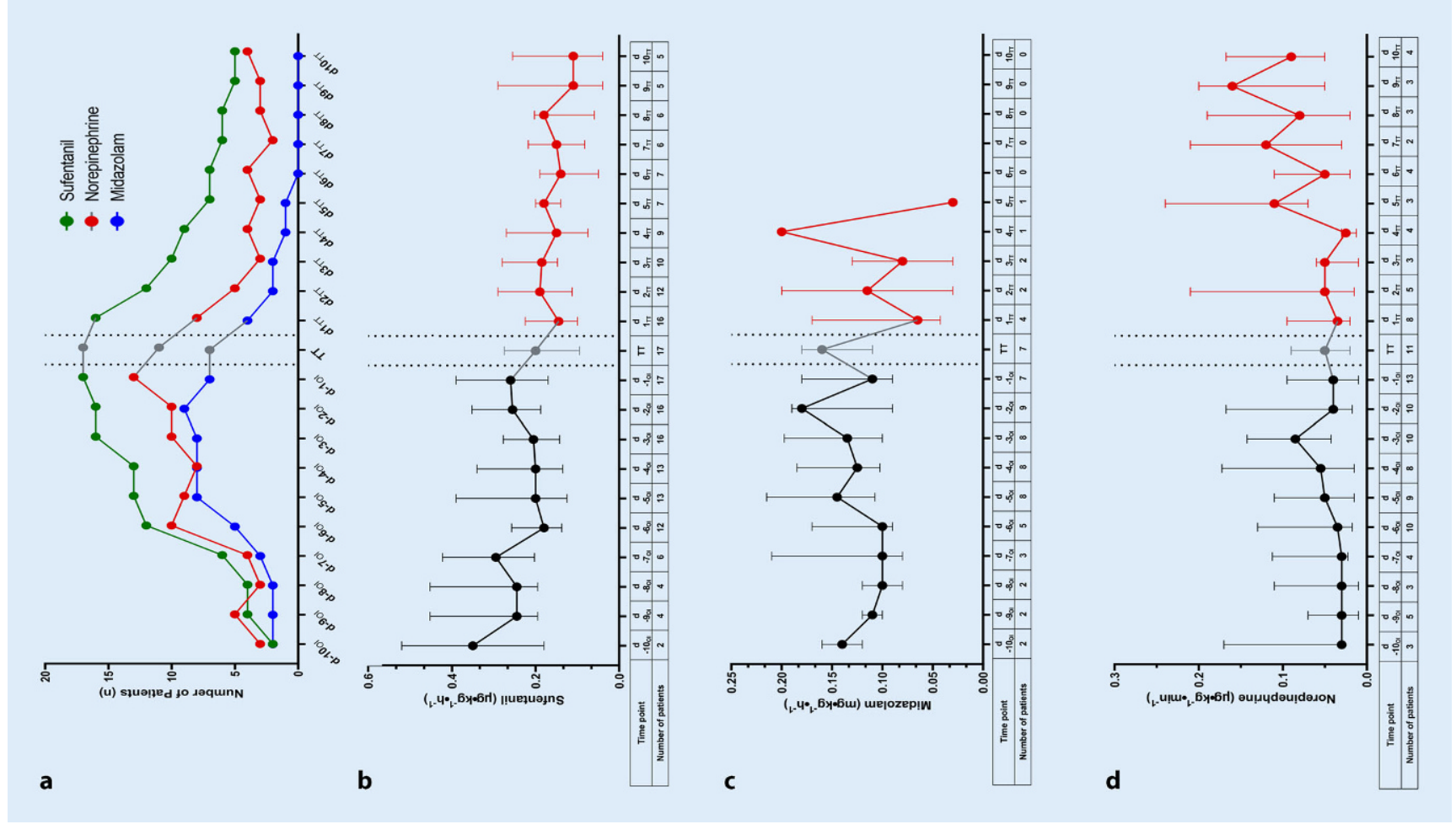

Fig. $3 \Delta$ Sedative medication. a Number of patients receiving midazolam, sufentanil, or norepinephrine at the different time points during ventilation. $b$ Doses of intravenous sufentanil $\left(\mu \mathrm{g} \cdot \mathrm{kg}^{-1} \cdot \mathrm{h}^{-1}\right)$ and total number of patients receiving sufentanil (table). $\mathrm{c}$ Doses of intravenous midazolam $\left(\mu \mathrm{g} \cdot \mathrm{kg}^{-1} \cdot \mathrm{h}^{-1}\right)$ and total number of patients receiving midazolam (table) at the different time points, and $\mathbf{d}$ doses of intravenous norepinephrine $\left(\mu \mathrm{g} \cdot \mathrm{kg}^{-1} \cdot \mathrm{h}^{-1}\right)$ and total number of patients receiving norepinephrine (table) at the different time points. Sedation was managed according to the Richmond Agitation and Sedation Scale (RASS). Data are presented as median and interquartile range

is displayed in - Fig. 2 c, d. The number of patients in prone position was reduced from seven on the day before tracheostomy to one patient at the day after tracheostomy. The number of patients requiring neuromuscular blocking agents was reduced from four to one. The maximum number of patients requiring dialysis or blood transfusion was five and four, respectively (• Fig. 2).

Sedative medication. After tracheostomy, the number of patients receiving sufentanil and midazolam decreased (• Fig. 3a). In line with a reduction in sedation, the number of patients in need for norepinephrine to maintain hemodynamic stability decreased as well.

\section{Infection parameters}

On admission, the median of the infection parameters C-reactive protein (CRP), interleukin (IL)-6, brain-type natriuretic peptide (BNP) and procalci- tonin were above the normal range in the peripheral blood. Leukocytes were in the normal range and lymphocytes were decreased (• Table 2 ).

\section{Discussion}

This single-center retrospective and observational study describes the clinical course of 18 critically ill COVID-19 patients with acute respiratory failure requiring mechanical ventilation. We included all patients with confirmed SARSCoV-2 infection, who received surgical tracheostomy because of invasive mechanical ventilation from March 27 to May 18, 2020.

Tracheostomy is a common procedure in critically ill patients who require prolonged mechanical ventilation and cannot be extubated. In COVID-19 patients, the optimal time point for tracheostomy is matter of considerable debate, mainly because of the high risk for virus transmission during the procedure $[2,21,38]$.
The American Academy of Otolaryngology-Head and Neck Surgery suggests delaying tracheostomy in patients with COVID-19 for as long as possible [9]. They recommend performing the procedure only in those patients who display clinical signs of improvement, which implies a reduced virus load. This is typically the case after 2-3 weeks of ventilation [23]. Although delaying tracheostomy for patients with COVID-19 might reduce infectious risks for staff, extended duration of oral intubation would include continuation of sedation as well as mechanical ventilation. Prolonged sedation increases the risk for critical illness myo- and neuropathy, which would lead to a prolonged ICU stay $[12,23]$. A tracheostomy can facilitate weaning from ventilation through a reduction in sedation with a faster conversion into a spontaneous ventilation mode and therefore potentially increase the availability of ICU beds, which may be important especially during the COVID- 


\begin{tabular}{|c|c|c|c|}
\hline Data point; median (range) & $\begin{array}{l}\text { Survivor } \\
(n=12)\end{array}$ & $\begin{array}{l}\text { Nonsurvivor } \\
(n=6)\end{array}$ & $\begin{array}{l}\text { Norm } \\
\text { range }\end{array}$ \\
\hline Urea (mmoL/L) & $11.3(3.3-21.6)$ & $10.8(4.1-14.1)$ & $3-9.2$ \\
\hline Creatinine $(\mu \mathrm{moL} / \mathrm{L})$ & $105(65-196)$ & $139(55-201)$ & $59-104$ \\
\hline Glomerular filtration rate (CKD-EPI) & $53(33-104)$ & $37(25-109)$ & - \\
\hline Bilirubin ( $\mu \mathrm{moL} / \mathrm{L})$ & $10(6-45)$ & $11(4-19)$ & $2-21$ \\
\hline Aspartate aminotransferase (U/L) & $82(53-126)$ & $52(24-128)$ & $<50$ \\
\hline Alanine aminotransferase (U/L) & $39(22-134)$ & $33(12-65)$ & $<45$ \\
\hline Gamma-glutamyl transferase (U/L) & $74(14-821)$ & $30(24-75)$ & $<60$ \\
\hline Alkaline phosphatase (U/L) & $70(29-345)$ & $51(36-77)$ & $40-130$ \\
\hline Creatine kinase (U/L) & $434(58-1741)$ & $218(10-2841)$ & $20-200$ \\
\hline Myoglobin ( $\mu \mathrm{g} / \mathrm{L})$ & $269(43-1191)$ & $161(21-740)$ & $28-72$ \\
\hline Troponin (ng/L) & $28(5-128)$ & $46(13-254)$ & $<14$ \\
\hline Procalcitonin ( $\mu \mathrm{g} / \mathrm{L})$ & $1.35(0.08-5.54)$ & $0.33(0.19-22.7)$ & $<0.046$ \\
\hline D-dimer (mg/L) & $2.4(1.0-5.1)$ & $2.5(1.7-3.9)$ & $<0.8$ \\
\hline Ferritin $(\mu \mathrm{g} / \mathrm{L})$ & $1,153(812-3717)$ & $1,356(280-8453)$ & $4-665$ \\
\hline C-reactive protein (mg/L) & $200(52-437)$ & $63(2-115)$ & $<5$ \\
\hline Lactate dehydrogenase (U/L) & $349(219-591)$ & $377(180-697)$ & $<250$ \\
\hline $\mathrm{BNP}(\mathrm{pg} / \mathrm{mL})$ & $813(116-3869)$ & $2,766(236-9670)$ & $<486$ \\
\hline Interleukin-6 (pg/mL) & $246(30-375)$ & $447(88-3140)$ & $<7$ \\
\hline White blood cell count $\left(\times 10^{9} / \mathrm{L}\right)$ & $9.1(3.0-19.0)$ & $5.8(3.9-11.1)$ & $4.4-11.3$ \\
\hline Lymphocyte count $\left(\times 10^{9} / \mathrm{L}\right)$ & $0.8(0.4-3.7)$ & $0.5(0.3-0.7)$ & $1.2-3.5$ \\
\hline Platelet count $\left(\times 10^{9} / \mathrm{L}\right)$ & $207(6-682)$ & $116(53-204)$ & $150-450$ \\
\hline
\end{tabular}

19 pandemic [23]. General recommendations in non-COVID patients with prolonged mechanical ventilation are to perform tracheostomy around day ten [32]. Early tracheostomy is frequently defined in the time frame of one week after intubation [30]. Overall, decision making for tracheostomy in COVID19 patients include considerations as reduced risk for ventilator-associated respiratory muscle atrophy, ability to communicate, cumulative effects of a reduced sedation, and maintenance of ICU capacity for an early time point as well as potential risks to health-care workers due to virus contamination [23] and to patients due to a potential risk of increased mortality for later time points beyond day 14-21 [15, 20, 28].

However, tracheostomy in general may facilitate some beneficial effects in COVID-19 patients and potentially be performed earlier considering the clinical presentation of the patient [22]:

I. In our institution, patients were placed in prone position for $16 \mathrm{~h}$ per day when they displayed severe hypoxemia under mechanical ventila- tion (Horovitz index $<100 \mathrm{~mm} \mathrm{Hg}$ ). Because most of our COVID-19 patients presented with an increased BMI, turning such patients is cumbersome and is associated with an increased risk for dislocation of the ventilation tube. This is particularly the case at times when ICU are understaffed and at the limit of their capacity. In patients with a surgical tracheostoma, the risk for cannula dislocation or accidental decannulation is reduced [3], and in case of a dislocation while patients are in prone position, re-cannulation is straightforward. Furthermore, in our cohort of COVID-19 patients, tracheostomy apparently reduced the number of patients in need for prone positing (• Fig. 2).

II. In our patients, tracheostomy led to a slightly less invasive ventilation. Apparently, there was a reduction in PEEP and PEAK pressure together with a slight increase in lung compliance (- Fig. 2). A decrease in PEEP as well as PEAK to ensure adequate oxygenation $\left(\mathrm{PaO}_{2}>60 \mathrm{~mm} \mathrm{Hg}\right)$ and ventilation $\left(\mathrm{PaCO}_{2}\right.$ within normal range for the individual patient considering $\mathrm{pH}$ values within 7.35 and 7.45), respectively, are signs of clinical improvement of lung function. Some guidelines recommend postponing tracheostomy until the patient has a $\mathrm{PEEP}$ requirement of $10 \mathrm{cmH}_{2} \mathrm{O}$ or less [1] so that patients more likely overcome the procedure, which stresses the value of PEEP to present a marker of lung function. Although there is a bigger range after tracheostomy, Horovitz index slightly increased after tracheostomy in our patient cohort, which indicates an improvement of oxygenation and lung function as well. A lower Horovitz index may present an independent risk factor for mortality in patients with COVID-19 [37].

III. SARS-CoV-2 has been reported to be found in the brain and cerebral fluid of human COVID-19 patients [34]. However, COVID-19 has not been described to impair the human brain function to a great extent. Patients are typically fully awake until transoral intubation, and their need for sedative medication is particularly high to tolerate the transoral ventilation tube and invasive ventilation with a high peak pressure. However, an extended period of deep sedation is associated with a prolonged weaning time in case of clinical improvement. In our patients, who had received tracheostomy, sedative medication was promptly reduced and stopped when tolerated by the patients.

IV. As in every other patient with severe hypoxemic respiratory failure requiring mechanical ventilation, patients with COVID-19 are at risk for extubation failure with the need for re-intubation. In case of extubation, COVID-19 patients are left with a hyperresponsive bronchopulmonal system because of the viral infection. Furthermore, other institutions report and increased number of laryngeal edema after extubation in COVID-19 patients, often leading to stridor and the 


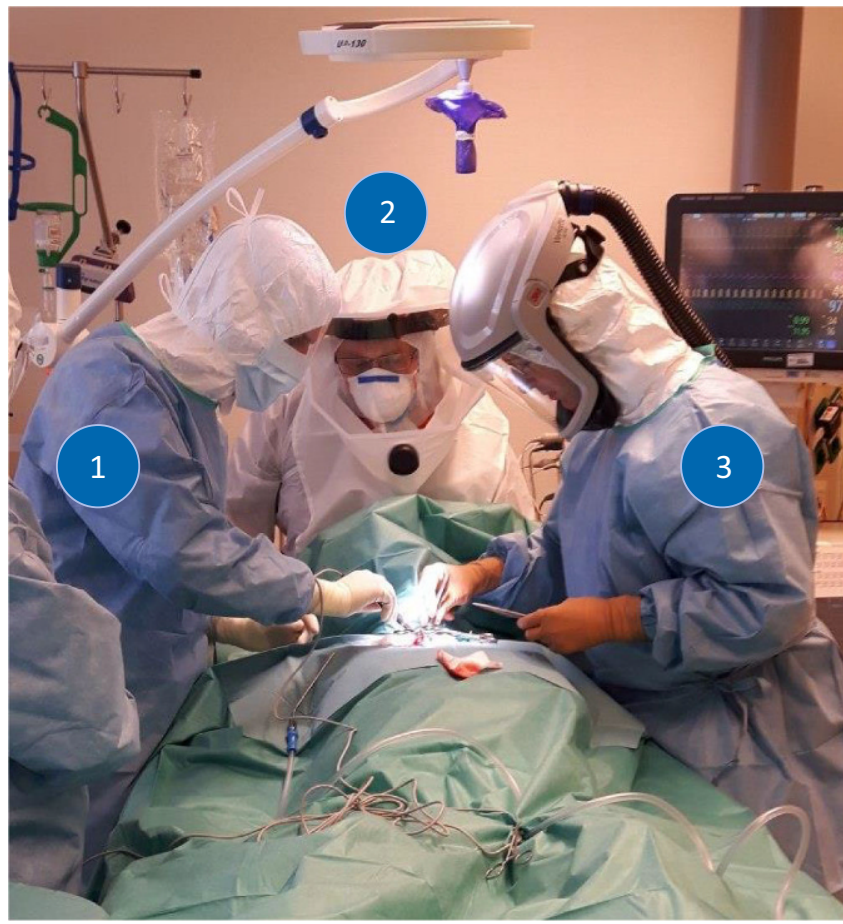

Fig. $4<$ Surgery setup. Open surgical tracheostomy was performed in the patient's bed in the intensive care unit. The patient was covered with sterile drapes. 1: First surgeon on the patient's right side with N99mask and facial shield; 2 : anesthetist with powered airpurifying respirator (PAPR) at the patient's head; 3: second surgeon on the patient's left side with PAPR. Reprint with permission $\odot$ W. Schmidt, all rights reserved

need for reintubation immediately. In many cases, these reintubations are reported to be difficult due to significant edema in patients who were originally straightforward intubations [5, 24]. An extubation failure may increase morbidity and mortality of COVID-19 patients even further [29] as well as increase the risk for health care workers due to aerosol generation. This is not the case in patients with tracheostoma because ventilation can be started and continued directly on the cannula via a closed loop system, independently from function of the upper airway.

The option to perform percutaneous dilatational tracheostomy had been discussed in our department because it is a less time-consuming procedure [3]. However, for the first pandemic period from March to May 2020 we decided against it, mainly because of the increased risk for virus transmission during pulling back of the dilator and opening of the trachea. Minor points were the increased risk for tube dislocation during the prone position and the fact that most of our patients presented with increased BMI and adipose stature, which is a rela- tive contraindication for percutaneous dilatational tracheostomy. Also, other university hospitals in Germany perform a surgical tracheostomy due to a shorter and more controlled aerosol exposure as well as surgical control of bleeding and waiving of bronchoscopy as another aerosol generating procedure [26]. Indeed, the same arguments were used during the SARS pandemic in 2004 [6].

All FONA procedures in COVID19 patients are potentially associated with increased aerosol generation and virus exposure [38]. Most authors who suggest delaying tracheostomy in COVID19 patients do so with reference to the increased risk for transmission during the procedure [9]. Fortunately, none of our staff, including surgeons, scrub nurses and anesthetists, were infected by SARS-CoV-2 at the time of data lock. Therefore, we suggest that surgical tracheostomy is a safe procedure in COVID-19 patients, when personal protection is worn and safety recommendations are followed [25]. In our setting, personal protection with N99mask and face shield was equally effective as a PAPR (• Fig. 4). Advantages of PAPR protection may include an increased safety by filtered air-flow and increased comfort. Furthermore, there are reports of SARS-CoV2 transmission despite protection via wearing a N99mask during cardiopulmonary resuscitation [7]. However, with PAPR there is an increased risk for self-contamination when doffing as observed during the Ebola outbreak in 2014 [27]. Because the virus is characterized by a prolonged surface stability, special care must be taken when cleaning PAPR equipment [31].

\section{Limitations}

Our study has several notable limitations. The number of patients treated is rather small. We found a series of apparent changes in ventilation parameters associated with the day of tracheostomy. We would like to underline that this association does not imply any correlation. The observed changes may as well have occurred during the intensive treatment period without any correlation to surgical tracheostomy.

\section{Conclusion}

Our data suggest that surgical tracheostomy is a safe procedure in patients with COVID-19. Tracheostomy may support a positive course of disease in COVID-19-infected patients with severe hypoxemic respiratory failure requiring mechanical ventilation. Recommendations for personal protection of surgical staff should be followed when protective material is available. Overall, patient risk factors as well as disease severity together with local factors and expertise must be considered when decisions are made for tracheostomy and the specific procedure in patients with COVID-19.

\section{Corresponding address}

\section{Patrick J. Schuler, MD}

Department of Oto-Rhino-Laryngology, Head and Neck Surgery, Ulm University Medical

Center

Frauensteige 12, 89075 Ulm, Germany patrick.schuler@uniklinik-ulm.de

Acknowledgements. We thank our colleagues for performing the surgical procedures and Walter Schmidt for providing the photograph. 
Funding. Open Access funding enabled and organized by Projekt DEAL.

\section{Declarations}

Conflict of interest. P.J. Schuler, J. Greve, T.K. Hoffmann, J. Hahn, F. Boehm, B. Bock, J. Reins, U. Ehrmann, E. Barth, K. Traeger, B. Jungwirth and M. Wepler declare that they have no competing interests.

For this article no studies with human participants or animals were performed by any of the authors. All studies performed were in accordance with the ethical standards indicated in each case.

Open Access. This article is licensed under a Creative Commons Attribution 4.0 International License, which permits use, sharing, adaptation, distribution and reproduction in any medium or format, as long as you give appropriate credit to the original author(s) and the source, provide a link to the Creative Commons licence, and indicate if changes were made. The images or other third party material in this article are included in the article's Creative Commons licence, unless indicated otherwise in a credit line to the material. If material is not included in the article's Creative Commons licence and your intended use is not permitted by statutory regulation or exceeds the permitted use you will need to obtain permission directly from the copyright holder. To view a copy of this licence, visit http://creativecommons.org/licenses/by/4.0/.

\section{References}

1. Bla (2020) British laryngological association tracheostomy guideline COVID 19. https:// www.britishlaryngological.org/sites/default/ files/BLA\%20Tracheostomy\%20guideline $\% 20$ \%20UPDATED\%20Nov\%202020.pdf

2. Botti C, Lusetti F, Castellucci A et al (2020) Safe tracheotomy for patients with COVID-19. Am J Otolaryngol 41:102533

3. Brass P, Hellmich M, Ladra A et al (2016) Percutaneous techniques versus surgical techniques for tracheostomy. Cochrane Database Syst Rev. https://doi.org/10.1002/14651858.CD008045. pub2

4. Brewster DJ, Chrimes N, Do TB et al (2020) Consensus statement: Safe Airway Society principles of airway management and tracheal intubation specific to the COVID-19 adult patient group. Med J Aust 212:472-481

5. Chao TN, Harbison SP, Braslow BM et al (2020) Outcomes after Tracheostomy in COVID-19 Patients. Ann Surg. 2020 Sep; 272(3):e181-e186. https://doi.org/10.1097/SLA.0000000000004166

6. Chee VW, Khoo ML, Lee SF et al (2004) Infection control measures for operative procedures in severe acute respiratory syndrome-related patients. Anesthesiology 100:1394-1398

7. Christian MD, Loutfy M, Mcdonald LC et al (2004) Possible SARS coronavirus transmission during cardiopulmonary resuscitation. Emerg Infect Dis 10:287-293

8. Force ADT, Ranieri VM, Rubenfeld GD et al (2012) Acute respiratory distress syndrome: the Berlin Definition. JAMA 307:2526-2533

9. Givi B, Schiff BA, Chinn SB et al (2020) Safety recommendations for evaluation and surgery of the head and neck during the COVID-19 pandemic. JAMA Otolaryngol Head Neck Surg 146:579-584

10. Grady MH (2020) Grady Memorial Hospital, Georgia, USA. COVID-19 Tracheostomy Process. internal communication.

11. Grasselli G, Pesenti A, Cecconi M (2020) Critical care utilization for the COVID-19 outbreak in lombardy, Italy: early experience and forecast during an emergency response. JAMA 323:1545-1546

12. Griffiths RD, Hall JB (2010) Intensive care unitacquired weakness. Crit Care Med 38:779-787

13. Guan WJ, Ni ZY, Hu Y et al (2020) Clinical characteristics of Coronavirus disease 2019 in China. NEngl J Med 382:1708-1720

14. Hosokawa K, Nishimura M, Egi Metal (2015) Timing of tracheotomy in ICU patients: a systematic review of randomized controlled trials. Crit Care 19:424

15. Hsu CL, Chen KY, Chang CH et al (2005) Timing of tracheostomy as a determinant of weaning success in critically ill patients: a retrospective study. Crit Care 9:R46-52

16. Karagiannidis $C$, Mostert $C$, Hentschker $C$ et al (2020) Case characteristics, resource use, and outcomes of 10021 patients with COVID19 admitted to 920 German hospitals: an observational study. Lancet Respir Med 8:853-862

17. Kinley CE (1965) A technique of tracheostomy. Can Med Assoc J 92:79-81

18. Kluge S, Janssens U, Welte T et al (2020) German recommendations for treatment of critically ill patients with COVID-19-version 3 : S1-guideline. Anaesthesist 69:653-664

19. Liao X, Wang B, Kang Y (2020) Novel coronavirus infection during the 2019-2020 epidemic: preparing intensive care units-the experience in Sichuan Province, China. Intensive Care Med 46:357-360

20. Lin WC, Chen CW, Wang JD et al (2015) Is tracheostomy a better choice than translaryngeal intubation for critically ill patients requiring mechanical ventilation for more than 14 days? A comparison of short-term outcomes. BMC Anesthesiol 15:181

21. Loth AG, Guderian DB, Haake B et al (2020) Aeroso exposure during surgical tracheotomy in SARScoV-2 positive patients. Shock. 2020 Sep 9. https:// doi.org/10.1097/SHK.0000000000001655. (Online ahead of print)

22. Mcgrath BA, Brenner MJ, Warrillow SJ (2020) Tracheostomy for COVID-19: business as usual? Br J Anaesth 125:867-871

23. Mcgrath BA, Brenner MJ, Warrillow SJ et al (2020) Tracheostomy in the COVID-19 era: global and multidisciplinary guidance. Lancet Respir Med 8:717-725

24. Mcgrath BA, Wallace S, Goswamy J (2020) Laryngeal oedema associated with COVID-19 complicating airway management. Anaesthesia 75:972

25. Miles BA, Schiff B, Ganly I et al (2020) Tracheostomy during the COV-SARS-coV-2 pandemic: recommendations from the New York head and Neck Society. https://www.nyheadandneck.org/ resources/COVID_tracheotomy.pdf

26. Pudszuhn A, Voegeler S, Berger C et al (2020) Elective tracheostomy in COVID-19 patients: experience with a standardized interdisciplinary approach. HNO 68:838-846

27. Roberts V (2014) To PAPR or not to PAPR? Can J Respir Ther 50:87-90

28. Rumbak MJ, Newton M, Truncale T et al (2004) A prospective, randomized, study comparing early percutaneous dilational tracheotomy to prolonged translaryngeal intubation (delayed tracheotomy) in critically ill medical patients. Crit Care Med 32:1689-1694

29. Seymour CW, Martinez A, Christie JD et al (2004) The outcome of extubation failure in a community hospital intensive care unit: a cohort study. Crit Care 8:R322-R327

30. Shaw JJ, Santry HP (2015) Who gets early tracheostomy?: evidence of unequal treatment at 185 academic medical centers. Chest 148:1242-1250

31. Van Doremalen N, Bushmaker T, Morris DH et al (2020) Aerosol and surface stability of SARS-CoV-2 as compared with SARS-coV-1. N Engl J Med 382:1564-1567

32. Vargas M, Sutherasan $Y$, Antonelli M et al (2015) Tracheostomy procedures in the intensive care unit: an international survey. Crit Care 19:291

33. Wu C, Chen X, Cai Y et al (2020) Risk factors associated with acute respiratory distress syndrome and death in patients with Coronavirus disease 2019 pneumonia in Wuhan, China. JAMA Intern Med 180:934-943

34. Wu Y, Xu X, Chen Z et al (2020) Nervous system involvement after infection with COVID-19 and other coronaviruses. Brain Behav Immun 87:18-22

35. Wu Z, Mcgoogan JM (2020) Characteristics of and important lessons from the Coronavirus disease 2019 (COVID-19) outbreak in China: summary of a report of 72314 cases from the Chinese center for disease control and prevention. JAMA 323:1239-1242

36. Zhou F, Yu T, Du R et al (2020) Clinical course and risk factors for mortality of adult inpatients with COVID-19 in Wuhan, China: a retrospective cohort study. Lancet 395:1054-1062

37. Zhou S, Yang Y, Zhang X et al (2020) Clinical course of 195 critically ill COVID-19 patients: a retrospective multicenter study. Shock 54:644-651

38. Zou L, Ruan F, Huang M et al (2020) SARS-CoV-2 Viral Load in Upper Respiratory Specimens of Infected Patients. N Engl J Med 382:1177-1179 
Hier steht eine Anzeige.

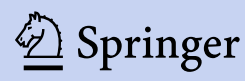

